\title{
First human clones get a cool response
}

\section{David Adam}

The announcement that researchers at a US biotech company had cloned human embryos from adult cells made headlines around the world earlier this week - and heightened the controversy surrounding 'therapeutic' cloning. But other researchers in the field question the claimed significance of the reported findings.

On 25 November, Advanced Cell Technology (ACT) of Worcester, Massachusetts, announced that it had created a cloned human embryo. It claimed this as an important step towards the goal of therapeutic cloning - in which cloned embryos would be used to harvest embryonic stem (ES) cells to grow replacement tissue perfectly matched to individual patients.

The ACT team fused adult cumulus cells - ovarian cells that surround eggs after ovulation - with human eggs that had been stripped of their own chromosomes. Three out of eight reconstructed eggs developed by dividing to form bundles of cells, with the best making it to six cells before stopping. Similar attempts to create embryos using skin cells met with failure.

Other groups have previously claimed to have cloned human embryos, but the ACT team is the first to publish its results (J. B. Cibelli et al. J. Regen. Med. 2,25-31;2001).

In a press release, the company said that the paper provides "the first proof that reprogrammed human cells can supply tissue". But other experts reject this claim and some even warn that ACT's results indicate that human therapeutic cloning will be much harder than animal studies suggest.

Before ES cells can be isolated from human embryos, they must form a hollow, fluid-filled ball of cells called a blastocyst. The ACT clones are "nowhere near" that stage, says Alan Colman, research director of PPL Therapeutics near Edinburgh, and a member of the team that cloned Dolly the sheep.

Colman also notes that the development of ACT's embryos compares unfavourably with experiments in animals. "Clearly, just extrapolating from the cow system into the human has not worked very well," he says. "With cows you would expect over $30 \%$ of the reconstructed eggs to go to the blastocyst stage."

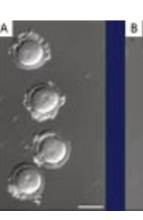

Jose Cibelli, ACT's vice-president of research and the paper's lead author, agrees the work is at an early stage but argues that it is still of interest: "We understand that these are early and preliminary results, but given the importance of this emerging field of medicine we decided to publish our results now."

While scientists debate the significance of ACT's findings, political opponents of cloning are attempting to outlaw the research. The US Senate is considering a bill, already passed by the House of Representatives, that would ban all forms of human cloning, both reproductive and therapeutic. Observers now

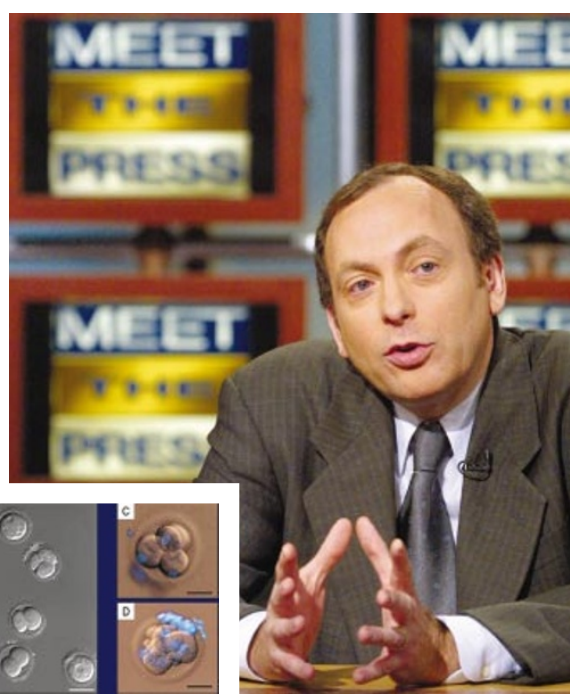

Michael West, chief executive of Advanced Cell Technology, discusses the cloned embryos (inset).

expect this to be passed, and to be signed into law by President George W. Bush.

Meanwhile, emergency legislation intended to outlaw human reproductive cloning will be debated in the British parliament this week - closing a legal loophole identified by the High Court (see Nature $414,381 ; 2001)$. The court ruling effectively leaves therapeutic cloning unregulated in Britain, although the government is appealing the decision.

www.liebertpub.com/ebi/default1.asp

\section{China caught out as model shows net fall in fish}

\section{Helen Pearson}

Despite a wealth of local evidence suggesting that world fish stocks are in peril, the United Nations' Food and Agriculture Organization (FAO) has consistently reported that global catch sizes are stable or rising.

But new research suggests that the FAO statistics, which have encouraged

FAO FISH
CATCH COMMITTEE

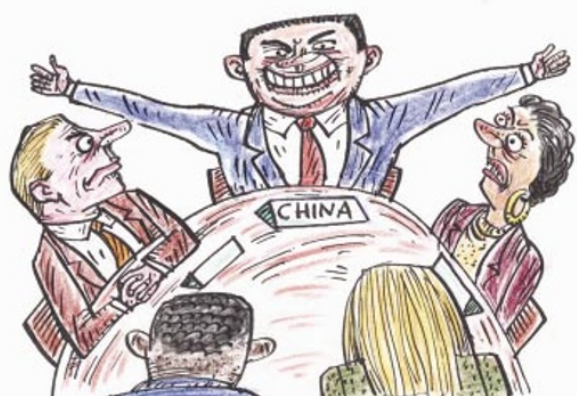

investment in the fishing industry, may have been distorted by exaggerated estimates of catch sizes by some countries - particularly China. The reality, say the researchers, is that fish stocks have declined alarmingly over the past decade.

The FAO classifies more than $70 \%$ of major marine fisheries as fully or overexploited. Many populations, such as the North Atlantic cod, have already crashed. But despite these warning signs, FAO statistics for total global fish catches have increased since 1950. These seemingly anomalous figures were put down to the discovery of new stocks.

Reg Watson and Daniel Pauly of the University of British Columbia in Vancouver, Canada, have now reanalysed the FAO statistics, using information about factors such as food abundance and water depth to predict catch levels. They report the results in this issue of Nature (see pages 534-536). Their model mirrored the FAO figures in most regions, but China's reported catches - which account for around $15 \%$ of the global harvest - are twice the predicted figure. If Watson and Pauly are correct, and China has over-reported its catches, world fish stocks have actually declined by more than $10 \%$ since 1988 .

"The results are stunning," says Jane Lubchenco, a marine biologist at Oregon State University in Corvallis. "We're on a trajectory of significant decline." Only a drastic overhaul of fishery management can halt the global trend, she says.

Local Chinese officials, whose promotion is linked to their ability to exceed production targets in the country's socialist economy, may be responsible for the overreporting, believes Pauly. The central Chinese government seemed to acknowledge the problem in 1998, when it placed a cap on the figures reported to the FAO.

Dropping stocks threaten the fishing industry and world food production. Fish provides more than $15 \%$ of the world's animal protein, and many developing countries in particular rely heavily on fish catches. 